\title{
PROCES AKTOTWÓRCZY W URZĘDZIE WOJEWÓDZKIM W TARNOWIE NA PRZYKŁADZIE WYDZIAŁU DO SPRAW WYZNAŃ (1975-1989)
}

\section{Słowa kluczowe}

Wydział do Spraw Wyznań, Urząd Wojewódzki w Tarnowie, Polska Ludowa, procesy aktotwórcze, obieg dokumentacji, czynności kancelaryjne, przepisy kancelaryjne

\section{Keywords}

Department of Religious Affairs, Voivodeship Office in Tarnów, Polish People's Republic, records creating processes, records circulation, office activity, office regulations

\section{Streszczenie}

Proces aktotwórczy jest integralną częścią szerzej rozumianych procesów archiwotwórczych stanowiąc, obok procesu archiwizacji, jeden z etapów tych procesów. Badanie

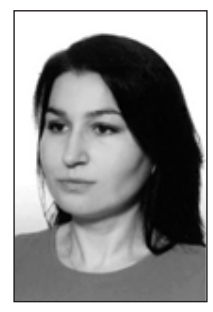

Barbara Bielaszka-Podgórny, historyk i archiwista, asystent w Instytucie Historii i Archiwistyki Uniwersytetu Pedagogicznego im. Komisji Edukacji Narodowej w Krakowie. Zainteresowania naukowe: kancelaria XX i XXI w., w tym urzędów administracji państwowej stopnia wojewódzkiego w okresie Polski Ludowej, zarządzanie dokumentacją współczesną z uwzględnieniem systemów elektronicznego zarzadzania dokumentacją i kształcenie archiwistów.

E-mail: barbara.bielaszka-podgorny@up.krakow.pl

ORCID ID: 0000-0002-9001-0098 
kancelarii, polegające na rekonstrukcji procesów archiwotwórczych, odgrywa istotną rolę w poznaniu zakresu kompetencji twórcy zespołu, jego funkcji i rzeczywistego charakteru działalności. Celem niniejszego artykułu jest przedstawienie procesów aktotwórczych, w wyniku których doszło do powstania akt Wydziału do Spraw Wyznań (WdSW) funkcjonującego w strukturze Urzędu Wojewódzkiego w Tarnowie. W artykule zarysowano zakres formalnych kompetencji WdSW i jego działalność w zakresie realizacji polityki wyznaniowej na terenie województwa tarnowskiego. W oparciu o analizę bogatej pozostałości aktowej wydziału przedstawiono organizację pracy kancelaryjnej, obieg dokumentacji jawnej, proces tworzenia dokumentów i formowania jednostek kancelaryjnych. Niniejszy artykuł kończy się omówieniem zasad przekazywania akt spraw ostatecznie zakończonych do archiwum zakładowego. Omawiane zagadnienia zostały przedstawione na tle analizy obowiązujących przepisów kancelaryjnych i praktycznej działalności referentów wydziału. W artykule zwrócono uwagę na brak dbałości w prawidłowym wykonywaniu czynności kancelaryjnych przez referentów, a w niektórych przypadkach na niestosowanie się przez nich do przepisów kancelaryjnych, co negatywnie wpłynęło na proces powstawania i narastania dokumentacji WdSW . Podstawę źródłową artykułu w pierwszej kolejności stanowią archiwalia wytworzone i zgromadzone w toku funkcjonowania WdSW Urzędu Wojewódzkiego w Tarnowie. Wykorzystano również wszelkie dostępne akty prawne, zwłaszcza zarządzenia i decyzje Wojewody Tarnowskiego, normatywy kancelaryjne i archiwalne oraz archiwalia wytworzone przez inne wydziały tarnowskiego urzędu wojewódzkiego, mające znaczenie dla omawianej problematyki.

\section{Summary}

Records creating process in the Voivodeship Office in Tarnów: case of the Department of Religious Affairs (1975-1989)

Records creating process is part of a broader concept of archives creating process, along with archiving process. Studying chanceries, i.e. reconstructing archives creating processes, plays an important role in reconstructing competencies, functions and actions of records creators. The aim of the study is to present records creating processes that led to creating records of the Department of Religious Affairs (DoRA), a part of the Voivodeship Office in Tarnów. The article outlines the scope of formal competencies of the department and its activity in religious politics in the Tarnów voivodeship. Based on analysis of rich documentary evidence, the article describes office organization, circulation of not-classified records, process of creating records and forming records folders. The article ends with description of regulations regarding transmission of finalized cases records to institution's archives. These questions were presented in context of analysis of office regulations and practice of department's clerks. The article stresses lack of attentiveness in clerks practice and even infracting office regulation; this had a negative impact on records creation in DoRA. The source base for the article consisted of, primarily, archival materials created and collected by DoRA. Apart from that, all possible regulations were analysed, like regulations issued by the Voivode in Tarnów, office and archives regulations, adequate archival materials created by other departments of the Voivodeship Office in Tarnów. 

D) roces aktotwórczy, obok procesu archiwizacji, jest integralną częścią szerzej
rozumianych procesów archiwotwórczych. Badanie kancelarii polegające na rekonstrukcji procesów archiwotwórczych należy do czołowych badań archiwistycznych ${ }^{1}$. Odgrywa ono istotną rolę w poznaniu kompetencji twórcy zespołu, jego funkcji i charakteru działalności². Proces archiwotwórczy został zdefiniowany przez Bohdana Ryszewskiego jako „ciąg działań dokonujący się w ramach funkcjonowania instytucji, w wyniku którego powstają dokumenty (akta) i następują relacje między nimi prowadzące do ukształtowania registratury oraz kolejnych działań dokonujących się w ramach archiwum, które przekształcają registraturę w zespół archiwalny"3. Procesy aktotwórcze, w trakcie których dochodzi do wytwarzania dokumentacji, przebiegają wyłącznie w kancelarii aktotwórcy, od momentu wpływu pierwszego pisma do kancelarii jednostki organizacyjnej do czasu wytworzenia się registratury ${ }^{4}$. Można je określić jako proces utrwalania się informacji w dokumentacji przepływającej w ramach danej

${ }^{1}$ Badanie kancelarii polegające na rekonstrukcji procesów aktotwórczych cieszy się coraz większym zainteresowaniem historyków i archiwistów. Wśród literatury poświęconej wspomnianemu zagadnieniu zob. np. H. Robótka, Kancelaria urzędów administracji publicznej w II Rzeczypospolitej (procesy aktotwórcze), Toruń 1993; Z. Chmielewski, Procesy aktotwórcze w polskich urzędach miejskich 1918-1939, Warszawa 1983; W. Bagieński, Procesy archiwotwórcze akt miejskich na Mazowszu na przykładzie Piaseczna w latach 1815-1950, Warszawa 1999; A. Barszcz, Prezydium Rady Ministrów i Urząd Rady Ministrów jako wytwórcy państwowego zasobu archiwalnego (1945-1996), Warszawa 2014; R. Leśkiewicz, Wojskowy Sąd Rejonowy w Poznaniu (1946-1955). Organizacja, funkcjonowanie, procesy archiwotwórcze, Warszawa-Poznań 2009; T. Karpiński, Procesy akto- $i$ archiwotwórcze $w$ sq̨downictwie wojskowym $w$ latach 1945-2010 na przykładzie sq̨dów poznańskich, Poznań 2013.

${ }^{2}$ Na temat miejsca badań nad kancelarią w warsztacie naukowym historyka i archiwisty zob. B. Ryszewski, Rozwój form kancelaryjnych w Polsce XIX i XX w., [w:] Nauki pomocnicze historii na XI Powszechnym Zjeździe Historyków Polskich w Toruniu, Warszawa-Łódź 1976, s. 86-89. Zob. także: R. Degen, Zarządzanie dokumentacja w polskich badaniach, [w:] Zarządzanie dokumentacją. Badania i dydaktyka, (Biblioteka Zarządcy Dokumentacji, t. 7), Toruń 2016, s. 37-58.

${ }^{3}$ B. Ryszewski, Problemy i metody badawcze archiwistyki, Toruń 1985, s. 89. Zob. także: L. Pudłowski, Archiwistyka a zarządzanie dokumentacją. Rola modeli cyklu życia $i$ continuum dokumentacji $w$ postrzeganiu wzajemnych zwiąków, [w:] Zatrzymać przeszłość, dogonić przyszłość. Pamiętnik VI Powszechnego Zjazdu Archiwistów Polskich, Wrocław 5-7 września 2012 r., red. W. Chorążyczewski, K. Stryjkowski, Warszawa 2013, s. 51-78; tenże, Model cyklu życia dokumentacji, „Archeion” 2014, t. 115, s. 177-225; Record lifecycle, [w:] Encyclopedia of archival science, ed. L. Duranti, P.C. Franks, Lanham-Boulder-New York-London 2015, s. 342-346.

${ }^{4}$ H. Robótka, Opracowanie i opis archiwaliów. Podręcznik akademicki, Toruń 2010, s. 244. 
struktury z uwzględnieniem jej powiązań zewnętrznych, w ciągu całego okresu działalności danego twórcy 5 . Proces ten obejmuje kilka etapów: powstawanie dokumentów, tworzenie jednostek kancelaryjnych i kształtowanie registratury. Przyjęte postulaty badawcze determinują konieczność zbadania organizacji kancelarii, obiegu pism i akt, archiwizacji akt oraz rekonstrukcji obiegu informacji. Niezbędne jest również poznanie kompetencji twórcy zespołu, wykonywanych funkcji oraz zakresu działania.

Celem niniejszego artykułu jest przedstawienie procesów aktotwórczych, w wyniku których doszło do powstania akt Wydziału do Spraw Wyznań (WdSW) funkcjonującego w strukturze Urzędu Wojewódzkiego w Tarnowie. W artykule przedstawiono organizację pracy kancelaryjnej, obieg dokumentacji jawnej, proces tworzenia dokumentów i formowania jednostek kancelaryjnych. Artykuł kończy się omówieniem zasad przekazywania akt spraw ostatecznie zakończonych do archiwum zakładowego. Omawiane zagadnienia zostały przedstawione na tle analizy obowiązujących przepisów kancelaryjnych i praktycznej działalności referentów wydziału.

Podstawę źródłową artykułu w pierwszej kolejności stanowią archiwalia wytworzone i zgromadzone w toku funkcjonowania WdSW Urzędu Wojewódzkiego w Tarnowie. Wykorzystano również wszelkie dostępne akty prawne, zwłaszcza Zarządzenia Wojewody Tarnowskiego, normatywy kancelaryjne i archiwalne oraz archiwalia wytworzone przez inne wydziały tarnowskiego Urzędu Wojewódzkiego mające znaczenie dla omawianej problematyki.

Pozostałość aktowa WdSW przekracza liczbę 1500 j.a. przechowywanych w przeważającej większości w zasobie tarnowskiego oddziału Archiwum Narodowego w Krakowie oraz, w niewielkiej liczbie, w Archiwum Zakładowym tarnowskiej delegatury Małopolskiego Urzędu Wojewódzkiego w Krakowie?. Archiwalia WdSW przechowywane w zasobie tarnowskiego Oddziału Archi-

${ }^{5}$ B. Ryszewski, Problemy i metody, s. 87; H. Robótka, Wspótczesna biurowość. Zagadnienia ogólne, (Biblioteka Zarządcy Dokumentacji, t. 1), Toruń 2010, s. 23-24, s. 80; taż, Kancelaria urzędów, s. 6-7.

${ }^{6}$ Artykuł nie omawia obiegu dokumentacji niejawnej powstałej i gromadzonej w toku funkcjonowania Wydziału do Spraw Wyznań, która przechodziła przez kancelarię tajną.

7 W zasobie Archiwum Zakładowego Małopolskiego Urzędu Wojewódzkiego w Krakowie Delegatura w Tarnowie (dalej AZ MUW Tar.) znajdują się 44 j.a. wytworzone i zgromadzone w toku funkcjonowania WdSW. Obecnie trwają prace nad przygotowaniem tych materiałów do przekazania do tarnowskiego oddziału Archiwum Narodowego w Krakowie. Informacja na temat prac zmierzających do przekazania archiwaliów została uzyskana od kierownika Archiwum Zakładowego Małopolskiego Urzędu Wojewódzkiego w Krakowie. Stan na 1 IX 2018 r. 
wum Narodowego w Krakowie wchodzą w skład zespołu „Urząd Wojewódzki w Tarnowie", oznaczonego numerem 354. Wymieniony wyżej zespół obejmuje 4508 j.a. z lat [1945] 1975-1998.

Początek działalności WdSW w strukturze Urzędu Wojewódzkiego w Tarnowie przypada na $1975 \mathrm{r}^{8}$ Zasięg jego działalności obejmował obszar województwa tarnowskiego. Powstało ono jako jedno z 49 województw w wyniku reformy wprowadzającej dwustopniowy podział administracyjny państwa ${ }^{9}$. Nowo utworzone województwo pod względem zajmowanego obszaru plasowało się na 43 miejscu w kraju ${ }^{10}$. Miastem wojewódzkim był Tarnów będący jednocześnie siedzibą diecezji tarnowskiej.

W momencie utworzenia województwa tarnowskiego swoją działalność rozpoczął Urząd Wojewódzki będący urzędem podległym wojewodzie, przy pomocy którego wykonywał on powierzone mu zadania jako organ administracji państwowej w województwie ${ }^{11}$.

Strukturę organizacyjną urzędu, zgodnie z zapisami zawartymi w pierwszym statucie organizacyjnym tej jednostki, tworzyło 19 wydziałów, w tym WdSW ${ }^{12}$. Nadzór nad działalnością wydziału sprawował Wojewoda Tarnowski, w zakresie zadań którego pozostawały sprawy z obszaru wyznań ${ }^{13}$. WdSW posiadał rozległy

8 Zarządzenie Nr 2/75 Wojewody Tarnowskiego z 4 VI 1975 r. w sprawie ustalenia tymczasowego zakresu działania i organizacji wewnętrznej Urzędu Wojewódzkiego, Archiwum Narodowe w Krakowie Oddział w Tarnowie (dalej: ANT), Urząd Wojewódzki w Tarnowie [1945] 1975-1998 (dalej UWT), sygn. 2725, k. 5-9. Autorka niniejszego opracowania przedstawiła organizację oraz formalne ramy działalności Wydziału do Spraw Wyznań Urzędu Wojewódzkiego w Tarnowie w odrębnej pracy. W związku z powyższym w prezentowanym artykule zostały nakreślone ogólne ramy funkcjonowania tarnowskiego WdSW. Zob. B. Bielaszka-Podgórny, Organizacja i zakres kompetencji Wydziału do Spraw Wyznań Urzędu Wojewódzkiego w Tarnowie w świetle archiwaliów zespołu „Urząd Wojewódzki w Tarnowie", [w:] Urząd do spraw Wyznań: struktury, działalność, ludzie, t. 1: Struktury wojewódzkie, wybrane aspekty funkcjonowania, red. R. Łatka [w druku].

9 Ustawa z 28 V 1975 r. o dwustopniowym podziale administracyjnym Państwa oraz o zmianie ustawy o radach narodowych (Dz. U., 1975, nr 16, poz. 91).

10 J. Warszyńska, Słowo wstępne, [w:] Województwo tarnowskie. Monografia, red. J. Warszyńska, Wrocław-Warszawa-Kraków-Gdańsk-Łódź 1988 r., s. 7.

${ }_{11} \S 1$ pkt 1 rozporządzenia Rady Ministrów z 30 V 1975 r. w sprawie zasad organizacji urzędów terenowych organów administracji państwowej (Dz. U., 1975, nr 17, poz. 93).

12 Zarządzenie Nr 28/75 Wojewody Tarnowskiego z 28 VII 1975 r. w sprawie statutu organizacyjnego Urzędu Wojewódzkiego w Tarnowie, Dziennik Urzędowy Wojewódzkiej Rady Narodowej (dalej Dz. Urz. WRN) w Tarnowie z 15 VIII 1975 r., Nr 1, poz. 1 z późn. zm. (dalej Zarządzenie Nr 28/75 Wojewody Tarnowskiego).

${ }^{13}$ Zob. § 3 pkt 2 i pkt 3 Zarządzenia Nr 51/77 Wojewody Tarnowskiego z 5 XI 1977 r. 
zakres kompetencji, który - od strony formalnej - precyzowały zapisy statutów i regulaminów organizacyjnych Urzędu Wojewódzkiego w Tarnowie ${ }^{14}$. Pełnił rolę koordynacyjną wszelkich działań podejmowanych w obszarze wyznaniowym na terenie województwa tarnowskiego ${ }^{15}$. Szczegółowy zakres działania wydziału po raz pierwszy został określony w statucie organizacyjnym urzędu z lipca 1975 r. $^{16}$. Do jego zadań należało prowadzenie spraw z zakresu stosunków między państwem a Kościołem i innymi związkami wyznaniowymi, w tym m.in. spraw z zakresu wykonywania przepisów o organizowaniu i obsadzaniu stanowisk kościelnych oraz dotyczących planów budownictwa kościelnego i sakralnego ${ }^{17}$. Formalne zadania wydziału w swym zasadniczym kształcie nie uległy zmianie w statutach i regulaminach organizacyjnych urzędu wprowadzanych w kolejnych latach ${ }^{18}$. Przez cały okres swojego istnienia, do końca 1989 r.,

w sprawie zakresu obowiązków wicewojewodów, AZ MUW Tar., Urząd Wojewódzki w Tarnowie (dalej: UWT), sygn. 677, nlb.

${ }^{14} \mathrm{~W}$ tym miejscu należy zaznaczyć, że analiza akt wytworzonych i zgromadzonych w toku funkcjonowania WdSW w Tarnowie pozwala na przedstawienie szerokiego spektrum zadań realizowanych przez wydział, który wykracza poza zakres formalnych kompetencji określonych w statutach i regulaminach organizacyjnych, oraz na ukazanie rzeczywistego sposobu realizacji powierzonych zadań. Na temat formalnych i rzeczywistych kompetencji administracji wyznaniowej, przedstawionych na przykładzie Urzędu do Spraw Wyznań (dalej: UdSW), zob. artykuł Henryka Misztala i Artura Mezglewskiego, Zarys kompetencji, styl działania i cele Urzędu ds. Wyznań, [w:] Prawo i polityka wyznaniowa w Polsce Ludowej. Materiały z II Ogólnopolskiego Sympozjum Prawa Wyznaniowego (Kazimierz Dolny, 26-28 października 2004 r.), red. A. Mezglewski, P. Stanisz, M. Ordon, Lublin 2005, s. 33-70.

15 AZ MUW Tar., UWT, sygn. 640: „Informacja dotycząca stosunków pomiędzy władzami administracyjnymi a kościelnymi w województwie tarnowskim", nlb. Podstawę prawną upoważniającą wydział do pełnienia funkcji koordynatora działań prowadzonych w obszarze wyznaniowym stanowiło Zarządzenie Nr 55/75 Wojewody Tarnowskiego, które na wszystkie podmioty nałożyło obowiązek uzgadniania decyzji mających związek ze sprawami wyznaniowymi, z WdSW. Zob. ANT, UWT, sygn. 3770: Zarządzenie Nr 55/75 Wojewody Tarnowskiego z 10 IX 1975 r. w sprawie postępowania wydziałów Urzędu Wojewódzkiego oraz terenowych organów administracji państwowej stopnia podstawowego dotyczących trybu, sposobu załatwiania i uzgadniania spraw wyznaniowych z Wydziałem do Spraw Wyznań Urzędu Wojewódzkiego w Tarnowie, k. 511.

16 Zarządzenie Nr 28/75 Wojewody Tarnowskiego.

17 Pkt 4 ppkt 1-10 załącznika Nr 3 do Zarządzenia Nr 28/75 Wojewody Tarnowskiego.

18 Por. Zarządzenie Nr 43/79 Wojewody Tarnowskiego z 31 XII 1979 r. w sprawie regulaminu organizacyjnego Urzędu Wojewódzkiego w Tarnowie (Dz. Urz. WRN w Tarnowie z 7 I 1980 r. Nr 1, poz. 1 z późn. zm); Zarządzenie Nr 33/84 Wojewody Tarnowskiego z dnia 14 VI 1984 r. w sprawie ustalenia regulaminu organizacyjnego Urzędu Wojewódzkiego w Tarnowie (Dz. Urz. Województwa Tarnowskiego z dnia 29 VI 
WdSW funkcjonował jako samodzielny wydział wyodrębniony w strukturze Urzędu Wojewódzkiego w Tarnowie.

Obsada etatowa wydziału należała do jednych z najmniej licznych w tarnowskim urzędzie, co odpowiadało tendencjom w innych Wydziałach do Spraw Wyznań. Najwyższy poziom zatrudnienia, obejmujący pięć etatów, odnotowano w pierwszych latach funkcjonowania WdSW ${ }^{19}$. Po 1980 r. liczba etatów sukcesywnie zmniejszała się ${ }^{20}$. Według dostępnych danych, w 1982 r. stan zatrudnienia w wydziale obejmował czterech pracowników ${ }^{21}$. Do kolejnych zmian w zakresie liczby zatrudnionych doszło w końcu lat osiemdziesiątych. W związku z wewnętrzną reorganizacją Urzędu Wojewódzkiego w Tarnowie i wiążącą się z nią redukcją zatrudnienia przeprowadzoną od 1 X 1988 r., liczbę etatów w wydziale zredukowano do trzech ${ }^{22}$, a następnie w 1989 r. do dwóch ${ }^{23}$.

Efektem produkcji kancelaryjnej wydziału jest bardzo zróżnicowana dokumentacja. W zasobie przeważa dokumentacja aktowa, obok niej dużą grupę

1984 r., nr 2, poz. 2 z późn. zm.); Zarządzenie Nr 11/88 Wojewody Tarnowskiego (ANT, UWT, sygn. 2646, k. 259-261).

19 ANT, UWT, sygn. 3621: „Zestawienie etatów i funduszu płac pracowników Urzędu Wojewódzkiego w Tarnowie", b.d., k. 73. W pierwszym roku funkcjonowania wydziału jeden etat nie został obsadzony. Zob. ANT, UWT, sygn. 2758: Załącznik Nr 11 do Decyzji Nr 114/75 Wojewody Tarnowskiego z dnia 22 XII 1975 r. w sprawie przyznania nagród pieniężnych dla pracowników Urzędu Wojewódzkiego w Tarnowie z tytułu zaoszczędzonego funduszu płac w wyniku nie obsadzenia etatów w 1975 r., k. 245. Zob. także: ANT, UWT sygn. 3555: „Wykaz wydziałów Urzędu Wojewódzkiego w Tarnowie”. Tab. nr 3, k. 81; tamże, sygn. 3621: „Etaty, struktura stanowisk i średnia płaca w zł według stanu na 31 lipca 1975 r.”, k. 445; tamże, sygn. 3573: „Rozmieszczenie etatów i funduszu płac na poszczególne wydziały Urzędu Wojewódzkiego w Tarnowie - liczba wakatów według stanu na 1 października 1978 r.”, k. 131; tamże, sygn. 3575: Pismo Biura Organizacyjno-Prawnego i Kadr UWT w Tarnowie do Ministra Administracji, Gospodarki Terenowej i Ochrony Środowiska w Warszawie w sprawie obsady etatowej komórek organizacyjnych Urzędu Wojewódzkiego w Tarnowie, 5 IV 1980 r., znak: Or. IV-1110-12/80, k. 49.

20 Zob. ANT, UWT, sygn. 3787: „Notatka w sprawie wewnętrznej reorganizacji urzędów wojewódzkich i ustawienia w nich problematyki wyznaniowej”, 23 XII 1987 r., k. 163. z

${ }^{21}$ ANT, UWT, sygn. 3577: „Etaty”, b.d., znak: Or.IV-1110-7/82, k. 41. Zob. także tamże, sygn. 3578: „Plan etatów i płac na 1.01.83”, b.d., k. 3.

${ }^{22}$ ANT, UWT, sygn. 3571: „Redukcja etatów od 1 października 1988 r. w Urzędzie Wojewódzkim w Tarnowie”, b.d., k. 75. Zob. także tamże, sygn. 2647: „Informacja dotycząca zmiany struktury organizacyjnej Urzędu Wojewódzkiego w Tarnowie w 1988 r.”, b.d., k. 47-53.

${ }^{23}$ ANT, UWT, sygn. 3552: „Zestawienie struktury zatrudnienia pracowników w Urzędzie Wojewódzkim w Tarnowie w latach 1988-1989”, b.d., k. 17. 
stanowi dokumentacja techniczna oraz w mniejszej liczbie geodezyjno-kartograficzna i fotograficzna. Zasób aktowy powstały w wyniku wieloaspektowej działalności tarnowskiego WdSW stanowi obecnie cenne źródło historyczne ${ }^{24}$.

Działalność kancelaryjna urzędów administracji państwowej w okresie PRL-u opierała się przede wszystkim na trzech normatywach kancelaryjno -archiwalnych: instrukcji kancelaryjnej, jednolitym rzeczowym wykazie akt oraz instrukcji o organizacji i zakresie działania archiwum zakładowego ${ }^{25}$. Po reformie administracji terytorialnej przeprowadzonej w 1975 r. kompetencje w zakresie opracowania projektów przepisów prawnych dotyczących organizacji i funkcjonowania urzędów terenowych organów administracji państwowej zostały powierzone Ministrowi Administracji, Gospodarki Terenowej i Ochrony Środowiska (Minister AGTiOŚ) ${ }^{26}$. W 1975 r. Minister AGTiOŚ wydał dwa zarządzenia wprowadzające normatywy regulujące narastanie dokumentacji w urzędach terenowych organów administracji państwowej: instrukcję kancelaryjną ${ }^{27}$ i jednolity rzeczowy wykaz akt ${ }^{28}$. Ostatni z normatywów, w postaci instrukcji o organizacji i zakresie działania archiwum zakładowego, został wprowadzony w 1976 r. mocą Zarządzenia nr 50/76 Ministra AGTiOŚ ${ }^{29}$. Wymienione regulacje

${ }^{24}$ Zasób aktowy tarnowskiego Wydziału do Spraw Wyznań omówiła B. Bielaszka-Podgórny, Wartość badawcza archiwaliów Wydziału do Spraw Wyznań Urzędu Wojewódzkiego w Tarnowie jako źródła do dziejów aparatu wyznaniowego PRL, „Pamięć i Sprawiedliwość” 2019, nr 33, s. 438-457.

${ }^{25}$ Szerzej na temat historii regulacji dotyczących postępowania z dokumentacją zob. H. Robótka, Wspótczesna biurowość. Zagadnienia ogólne (Biblioteka Zarządcy Dokumentacji, t. 1), Toruń 2010, s. 25-61; I. Radtke, Kancelaria wspótczesna, „Archeion” 1999, t. 100, s. 31-34; E. Perłakowska, Ewolucja zarządzania dokumentacja $w$ podmiotach publicznych, [w:] Dokumentacja elektroniczna w podmiotach publicznych, red. G. Szpor, Warszawa 2013, s. 23-29.

${ }^{26} \S 2$ pkt 2 lit. r) rozporządzenia Rady Ministrów z 9 VII 1975 r. w sprawie szczegółowego zakresu działania Ministra Administracji, Gospodarki Terenowej i Ochrony Środowiska (Dz. U., 1975, nr 26, poz. 136).

27 Zarządzenie nr 34 Ministra Administracji, Gospodarki Terenowej i Ochrony Środowiska z dnia 26 XI 1975 r. w sprawie wprowadzenia instrukcji kancelaryjnej w urzędach terenowych organów administracji państwowej (niepublikowane).

${ }_{28}$ Zarządzenie nr 36 Ministra Administracji, Gospodarki Terenowej i Ochrony Środowiska z dnia 12 XII 1975 r. w sprawie ustalenia jednolitego rzeczowego wykazu akt w urzędach terenowych organów administracji państwowej (niepublikowane).

${ }_{29}$ Zarządzenie nr 50/76 Ministra Administracji, Gospodarki Terenowej i Ochrony Środowiska z dnia 29 XI 1976 r. w sprawie ustalenia instrukcji o organizacji i zakresie działania archiwów zakładowych w urzędach terenowych organów administracji państwowej (niepublikowane). 
obowiązywały do 1990 r., z wyjątkiem instrukcji kancelaryjnej, która została zmieniona w $1987 \mathrm{r}^{30}$.

W tarnowskim urzędzie wojewódzkim obowiązywał bezdziennikowy system kancelaryjny oparty na jednolitym rzeczowym wykazie akt o dziesiętnym sposobie sygnowania ${ }^{31}$. W zdecentalizowanym wariancie biurowości, który obowiązywał w tej jednostce, do wykonywania czynności kancelaryjnych zobowiązani byli wszyscy referenci, w kompetencjach których pozostawało merytoryczne załatwienie sprawy. Tryb i zasady wykonywania czynności kancelaryjnych określała instrukcja kancelaryjna. Zawierała definicje podstawowych pojęć, wykaz podstawowych czynności kancelaryjnych oraz wskazanie osób w urzędzie, do których należało ich wykonywanie. Normowała czynności kancelarii, sekretariatów, referentów oraz hali maszyn. Regulowała zasady przydzielania korespondencji (wpływów), wewnętrznego obiegu akt w urzędzie, a także prowadzenia rejestrów kancelaryjnych. Szczegółowo określono w niej obowiązujący system kancelaryjny, zasady budowy wykazu akt, zasady rejestracji spraw, łączenia akt w sprawy i znakowania akt, załatwiania spraw, aprobaty i podpisywania pism, sporządzania czystopisów, wysyłania i doręczania pism, przechowywania akt bieżąco realizowanych, zasady przekazywania akt ostatecznie zrealizowanych do archiwum zakładowego oraz nadzór nad wykonywaniem czynności kancelaryjnych. Nadzór nad ich prawidłowym wykonywaniem należał do obowiązków dyrektora WdSW, w kompetencjach którego leżało sprawdzanie prawidłowości stosowania instrukcji kancelaryjnej przez referentów ${ }^{32}$.

30 Zarządzenie nr 4 Ministra - Szefa Urzędu Rady Ministrów z 7 IV 1987 r. w sprawie wykonywania czynności kancelaryjnych w urzędach terenowych organów administracji państwowej (niepublikowane).

${ }^{31}$ Rozdz. 7 pkt 1 Instrukcji kancelaryjnej dla urzędów terenowych organów administracji państwowej, Ministerstwo Administracji, Gospodarki Terenowej i Ochrony Środowiska, Warszawa - listopad 1975 (dalej: Instrukcja kancelaryjna, 1975). W przypadku kiedy treść poszczególnych zapisów Instrukcji kancelaryjnej z 1975 r. nie uległa zmianie w wersji Instrukcji kancelaryjnej z 1987 r., w cytatach przytaczano jedynie zapisy pierwszego z wyżej wymienionych normatywów.

$32 \S 51$, pkt 1-2 Instrukcji kancelaryjnej, 1975. Por. § 35 Instrukcji kancelaryjnej dla urzędów terenowych organów administracji państwowej, Urząd Rady Ministrów, Warszawa 1987 (dalej: Instrukcja kancelaryjna, 1987). Warto zwrócić uwagę na fakt, że zagadnienia z zakresu instrukcji kancelaryjnej, obok pytań obejmujących wiedzę z obszaru sześciu innych normatywów, znalazły się w turnieju wiedzy zorganizowanym w tarnowskim Urzędzie Wojewódzkim w 1976 r. dla pracowników tej instytucji. Wskazuje to na dbałość ze strony władz o podnoszenie kwalifikacji zawodowych pracowników i pogłębianie wiedzy z zakresu przepisów kancelaryjnych. Zob. ANT, UWT, sygn. 2478: Pismo Biura 
Zasady obiegu dokumentacji w urzędzie regulowały przepisy instrukcji kancelaryjnej. Na drogę urzędową dokumentu składały się poszczególne etapy (punkty zatrzymania), w ramach których wykonywano kolejne czynności kancelaryjne ${ }^{33}$ od momentu wszczęcia sprawy do momentu jej zakończenia i przekazania do archiwum bieżącego. Realizowane one były przez kancelarię, sekretariaty Wojewody, referentów, halę maszyn i archiwum zakładowe ${ }^{34}$. W bezdziennikowym systemie kancelaryjnym, uwzględniającym tylko niezbędne punkty zatrzymania, obieg akt odbywał się bez pokwitowania. Pierwszym etapem obiegu było przyjęcie pisma w kancelarii. Następnie, po odciśnięciu pieczątki wpływu, przekazywano korespondencję właściwym wydziałom, z wyjątkiem tej adresowanej do Wojewody i przeznaczonej do jego wglądu ${ }^{35}$. Po otrzymaniu pism wpływających dyrektor Wydziału do Spraw Wyznań dokonywał przeglądu korespondencji i po zapoznaniu się z jej treścią dekretował pisma, powierzając je właściwym pracownikom do prowadzenia. Dekretacja nanoszona była odręcznie bezpośrednio na pisma. Często przyjmowała postać dłuższej adnotacji zawierającej dyspozycje odnośnie do sposobu i trybu załatwienia sprawy oraz datę sporządzenia dekretacji i podpis dekretującego ${ }^{36}$. Do przekazywania dyspozycji dekretujący stosował tzw. skróty typowe ${ }^{37}$.

Organizacyjno-Prawnego i Kadr UWT w Tarnowie do WdSW UWT w Tarnowie w sprawie przygotowania pracowników do turnieju wiedzy ze znajomości niektórych przepisów normatywnych, 6 X 1976 r., znak: RZ/10/127/76, k. 101-106.

${ }^{33}$ H. Robótka, Wspótczesna biurowość, s. 86.

34 § 3 pkt 1 Instrukcji kancelaryjnej, 1975.

35 Zob. § 6 pkt 1 Instrukcji kancelaryjnej, 1975.

36 Zob. np. ANT, UWT, sygn. 3787: Pismo Ministra Szefa Urzędu Rady Ministrów do Wojewodów, Prezydentów Miast: stołecznego Warszawy, Krakowa, Łodzi, w sprawie ustawy z dnia 17 maja 1989 r. o stosunku Państwa do Kościoła Katolickiego w Polskiej Rzeczypospolitej Ludowej, 4 IV 1989 r., znak: ad. P.I.14-53/89/SF, k. 182; AZ MUW Tar., UWT, sygn. 666: Pismo Dyrekcji Okręgowej Dróg Publicznych w Krakowie do WdSW UWT w Tarnowie w sprawie ustalenia terminu wizji terenowej, 11 IV 1985 r., znak: DOPD.19.624.WW/18/84, nlb.

${ }^{37}$ Najczęściej stosowanym przez dekretujących skrótem był skrót „p.m.” („proszę mówić”), który oznaczał, że otrzymujący wpływ powinien w tej sprawie mówić z wydającym dyspozycję (§ 8 pkt 3 Instrukcji kancelaryjnej, 1975). Do przekazywania dyspozycji stosowano również inne skróty: „p.r.” („proszę referować”) - oznaczał, że otrzymujący wpływ po przygotowaniu projektu załatwienia powinien omówić go z osobą wydającą dyspozycję”; „m.a.” („moja aprobata”) - oznaczał, że wydający dyspozycje zachowuje dla siebie ostateczną aprobatę załatwienia; „m.p.”(„,mój podpis”) - oznaczał, że wydający dyspozycje zastrzega sobie prawo podpisania czystopisu załatwienia; „aa”(,ad acta”) oznaczał, że sprawę należy odłożyć do akt (tamże). 
Do kompetencji referentów wydziału należało rejestrowanie spraw, zakładanie jednostek kancelaryjnych, oznaczanie pism znakami spraw zgodnie z rzeczowym wykazem akt, łączenie akt z poprzednikami, merytoryczne załatwienie sprawy, opracowywanie projektów pism (w przypadku krótszych pism sporządzenie czystopisu), sprawdzenie zgodności czystopisu z konceptem pisma (kolacjonowanie), dołączenie załączników do pisma i przygotowanie go do wysyłki, dołączenie kopii odpowiedzi do właściwej jednostki kancelaryjnej, przechowywanie spraw bieżąco załatwianych oraz ostatecznie załatwionych, ale niezbędnych do dalszego wykonywania bieżącej pracy oraz przekazywanie akt spraw ostatecznie załatwionych do archiwum zakładowego.

Sprawę zazwyczaj wszczynało pismo wpływające do urzędu. Jeżeli było to pierwsze pismo wszczynające sprawę, referent był zobligowany do zarejestrowania go w spisie spraw. Rejestracja sprawy polegała na wpisaniu pisma wszczynającego sprawę pod kolejną pozycją w spisie spraw (lub w rejestrze kancelaryjnym), założonym zgodnie z jednolitym rzeczowym wykazem akt oraz nadanie jej znaku ${ }^{38}$. Znak sprawy stanowił jej stałą cechę rozpoznawczą. Zgodnie z zasadami obowiązującymi w systemie kancelaryjnym bezdziennikowym, znak sprawy nadawany był całej sprawie, a nie poszczególnym pismom. Narastanie dokumentów w danej sprawie podyktowane było kolejnością wpływu lub sporządzenia pisma. Na znak sprawy składał się: symbol hasła według jednolitego rzeczowego wykazu akt, kolejny numer zapisu w spisie spraw oraz dwie ostatnie cyfry roku, w którym sprawę wszczęto ${ }^{39}$. Na początku znaku spraw rejestrowanych w poszczególnych wydziałach urzędu podawano symbol wydziału i oddziału (jeżeli dany wydział się na nie dzielił). W przypadku Wydziału do Spraw Wyznań stosowano następujące symbole: Wz.I, Wz.II, Wz.III i Wz.IV. Dla przykładu znak sprawy Wz.I-6840/1/87 oznacza, że sprawa należy do grupy spraw oznaczonych w jednolitym rzeczowym wykazie akt hasłem „Nadzór nad Kościołem rzymsko-katolickim"40. Sprawa wszczęta w WdSW w 1987 r. została zarejestrowana $\mathrm{w}$ spisie spraw pod pozycją nr 1. Jako separatorów oddzielających poszczególne składniki znaku sprawy stosowano myślniki, ukośniki i kropki. Nierzadko znak sprawy składał się z dodatkowych elementów. Przykładowo, znaki spraw nadawane przez referenta, do obowiązków którego nale-

38 Przy znakowaniu akt Wydział stosował symbol literowy Wz, który został formalnie ustalony w statucie organizacyjnym Urzędu Wojewódzkiego. Zob. Zarządzenie Nr 28/75 Wojewody Tarnowskiego.

$39 \S 12$ pkt 3 Instrukcji kancelaryjnej, 1975.

40 Jednolity rzeczowy wykaz akt dla terenowych organów administracji państwowej, Warszawa 1975, s. 101. 
żało m.in. prowadzenie spraw ogólnoorganizacyjnych Wydziału (symbol Wz.I) prezentują się następująco: Wz-I-6870-73/76/77, Wz.I.6826/"N"/1/77 (symbol „N" stosowany był w przypadku aktów normatywnych ${ }^{41}$ ), Wz.I.6826/M/1/78 (symbol „M" stosowano na oznaczenie korespondencji przychodzącej w postaci zarządzeń i pism ministerialnych ${ }^{42}$ ), Wz.I-6526/Og/6/84 (symbol „Og” oznaczał sprawy ogólne ${ }^{43}$ ), Wz.I. 6826/Pf/W/82 (symbol „W” stosowany był w przypadku oznaczania spraw napływających z instytucji centralnych mających siedzibę w Warszawie, przede wszystkim z Urzędu do Spraw Wyznań. Oznaczenie „W” odnosiło się w tym wypadku do spraw określonych w tytule teczek jako „Sprawy warszawskie”. Wówczas znak sprawy był uzupełniany dodatkowo o symbol „Pf” ze względu na poufny charakter pism ${ }^{44}$. Ten sam symbol („W") był również stosowany w przypadku pism i zarządzeń Wojewody Tarnowskiego ${ }^{45}$. Należy zwrócić uwagę na brak konsekwencji w stosowaniu przez referentów niektórych z wymienionych symboli w znakach spraw. Dotyczy to m.in. zarządzeń Wojewody Tarnowskiego, które gromadzone były zarówno w jednostkach opatrzonych tytułem „Zarządzenia Wojewody Tarnowskiego”, jak i „Akta normatywne”, a co za tym idzie znaki spraw nadane przez referentów WdSW posiadają symbol „N" oraz („W”).

Analiza akt pozwoliła na wysunięcie stwierdzenia, że pracownicy wydziału w większości prawidłowo rejestrowali sprawy w oparciu o obowiązujący jednolity rzeczowy wykaz akt. Jednak w przypadku, gdy brzmienie haseł klasyfikacyjnych zawartych w wykazie akt nie odpowiadało treści wytwarzanej

${ }^{41}$ Zob. AZ MUW Tar., UWT, sygn. 663: Zarządzenie Nr 22/78 Wojewody Tarnowskiego z 31 V 1978 r. zmieniające zarządzenie w sprawie obowiązków wicewojewodów, nlb.; tamże: Pismo Wojewody Tarnowskiego do Prezydenta Miasta Tarnowa, Naczelników Miast, Miast i Gmin oraz Gmin, Dyrektorów Wydziałów UWT w Tarnowie w sprawie przestrzegania zasad ochrony tajemnicy państwowej i służbowej, 24 V 1978 r., znak: SW.Pf.IV.6313/30/78, nlb. Wewnętrzne akty prawne nie były rejestrowane w rejestrach kancelaryjnych. Taką możliwość dawały przepisy kancelaryjne. Zob. § 14 pkt 2 Instrukcji kancelaryjnej, 1987.

42 Zob. AZ MUW Tar., UWT, sygn. 664: Pismo przewodnie V Dyrektora UdSW do Dyrektora WdSW UWT w Tarnowie w sprawie listu Konferencji Episkopatu do księży pracujących na wsi, 30 VI 1978 r., nlb.

${ }^{43}$ Zob. tamże, sygn. 640: Pismo WdSW UWT w Tarnowie do Biura Organizacyjno-Prawnego Kadr i Kontroli UWT w Tarnowie dotyczące współpracy Uniwersytetu Jagiellońskiego z Wojewodą Tarnowskim, 1 III 1984 r., znak: Wz.I-6826/Og/6/84 r., nlb.

44 Zob. tamże, sygn. 642: Pismo poufne WdSW UWT w Tarnowie do UdSW w sprawie porozumienia ze spotkania Wojewody Tarnowskiego z Ordynariuszem Diecezji Tarnowskiej bp. Jerzym Ablewiczem, 7 VII 1982 r., znak: Wz.I.6826/Pf/W/82, nlb.

45 Zob. tamże, sygn. 640: Spis spraw w jednostce kancelaryjnej „Pisma i zarządzenia Wojewody Tarnowskiego" pochodzącej z 1984 r., nlb. 
dokumentacji, referenci rozszerzali obowiązujący wykaz akt o nowe hasła klasyfikacyjne oznaczone odrębnymi symbolami cyfrowymi. Powyższa praktyka stosowana była przede wszystkim przez referentów, do obowiązków których należało prowadzenie spraw ogólnoorganizacyjnych wydziału (symbol Wz.I), spraw dotyczących cmentarnictwa wyznaniowego i komunalnego, regulacji prawnej majątków Kościoła rzymskokatolickiego (symbol Wz.IV) oraz spraw z zakresu budownictwa kościelnego i sakralnego (symbol Wz.III). W pierwszym z wymienionych przypadków referent, rejestrując sprawy o charakterze administracyjnym, wytwarzane i gromadzone w toku funkcjonowania WdSW, najczęściej stosował symbol klasyfikacyjny $6826^{46}$, który stanowił rozszerzenie klasy 682 „Obsadzanie stanowisk kościelnych i duchownych”47. W trakcie rejestrowania spraw posługiwał się również symbolem $6802^{48}$. Ów symbol stanowił rozwinięcie klasy 680 „Przepisy prawne dotyczące spraw wyznaniowych”49. Referent zajmujący się sprawami cmentarnictwa w trakcie rejestracji prowadzonych spraw najczęściej posługiwał się symbolem klasyfikacyjnym $6876^{50}$ stanowiącym rozszerzenie klasy 687 „Dochody związków wyznaniowych, zakonów, kongregacji i stowarzyszeń kościelnych" ${ }^{51}$. Z kolei w toku rejestrowania spraw

${ }^{46}$ Zob. np. Pismo WdSW UWT w Tarnowie do Dyrektora Zespołu UdSW, Aleksandra Wołowicza, w sprawie informacji dotyczącej budownictwa kościelnego i sakralnego zrealizowanego w latach 1979-1983 na terenie województwa tarnowskiego, 12 VIII 1983 r., znak: Wz.I. 6826/pf/4/83 (AZ MUW Tar., UWT, sygn. 641, nlb.). Zob. także oznakowanie dokumentacji dotyczącej spraw ogólnoorganizacyjnych przy wykorzystaniu symbolu klasyfikacyjnego 6826 w następujących jednostkach: AZ MUW Tar., UWT, sygn. 640-642, 663-664, 669; 673, 677; ANT, UWT, sygn. 3765-3768, 3770-3774, 3777-3784, 3787.

47 Jednolity rzeczowy wykaz akt, s. 100.

48 Zob. np. AZ MUW Tar., UWT, sygn. 640: Pismo Ministra Pracy, Płac i Spraw Socjalnych do Ministra Kierownika UdSW, Adama Łopatki, dotyczące rozporządzenia Rady Ministrów z dnia 6 VIII 1983 r. w sprawie obowiązkowego pośrednictwa pracy na niektórych terenach oraz obowiązku zatrudnienia na całym terytorium kraju określonych kategorii osób ze względów społecznych, 31 XII 1983 r., znak sprawy nadany w WdSW UWT w Tarnowie: Wz.I.6802/1/"N"/84, nlb. Zob. także oznakowanie innych dokumentów zgromadzonych w wyżej wymienionej jednostce, przy rejestracji których wykorzystano symbol klasyfikacyjny 6802 (Tamże, nlb.).

49 Jednolity rzeczowy wykaz akt, s. 99.

50 Zob. np. AZ MUW Tar., UWT, sygn. 666: Pismo WdSW UWT w Tarnowie do Dyrektora Zespołu UdSW, Tadeusza Dusika, w sprawie informacji dotyczących cmentarzy żydowskich na terenie województwa tarnowskiego, 19 II 1985 r., znak: Wz.IV-6876/2/85, nlb. Zob. także oznakowanie dokumentacji przy wykorzystaniu symbolu klasyfikacyjnego 6876 w jednostkach: tamże, sygn. 659-662, 665.

51 Jednolity rzeczowy wykaz akt, s. 101. 
dotyczących regulacji prawnej majątków Kościoła rzymskokatolickiego referent stosował symbol $6875^{52}$, który był rozwinięciem klasy 687 „Dochody związków wyznaniowych, zakonów, kongregacji i stowarzyszeń kościelnych" ${ }^{53}$. Natomiast referent, w kompetencjach którego pozostawało prowadzenie spraw dotyczących budownictwa sakralnego i kościelnego, w czasie rejestracji wykorzystał symbol klasyfikacyjny $6816^{54}$ będący rozszerzeniem klasy 681 „Organizacja instytucji wyznaniowych" 55 .

Po zarejestrowaniu sprawy w spisie spraw referenci przystępowali do jej załatwienia. Instrukcja dopuszczała dwie formy załatwienia sprawy: ustną i pisemną. W sytuacjach wyjątkowo pilnych przepisy kancelaryjne pozwalały również na załatwienie spraw drogą teleksową, telefoniczną lub telegraficzną ${ }^{56}$. Przy pisemnym załatwianiu spraw stosowano formę brulionową, później określoną mianem korespondencyjnej ${ }^{57}$, i odręczną. Forma odręczna, będąca skróconym sposobem załatwienia sprawy, polegała na sporządzeniu przez referenta po zarejestrowaniu sprawy zwięzłej odpowiedzi załatwiającej sprawę bezpośrednio na otrzymanym piśmie lub na sporządzeniu na nim odręcznej notatki wskazującej na sposób jej załatwienia ${ }^{58}$. Przykładem spraw, przy załatwianiu których stosowano formę odręczną, są pisma zawierające prośbę o zezwolenie na zwołanie i przeprowadzenie zgromadzeń religijnych nierzymskokatolickich Kościołów i związków wyznaniowych. Wówczas referent załatwiający sprawę pod treścią pisma odciskał pieczęć nagłówkową WdSW, a następnie nanosił maszynowo zwięzłą odpowiedź załatwiającą sprawę bezpośrednio na piśmie. Przykładowa treść odpowiedzi prezentuje się następująco: „Wydział do Spraw Wyznań UW w Tarnowie stwierdza, że Świadkowie Jehowy są wyznaniem tolerowanym

52 ANT, UWT, sygn. 3837: Pismo WdSW UWT w Tarnowie do Spółdzielni Kółek Rolniczych w Rzeszowie w sprawie orzeczenia o probostwie Parafii Rzymskokatolickiej w Rzezawie, 19 XII 1980 r., znak: Wz.IV-6875/22/80, k. 49. Zob. także oznakowanie dokumentacji przy wykorzystaniu symbolu klasyfikacyjnego 6875 tamże, sygn. 3838-3839.

53 Jednolity rzeczowy wykaz akt, s. 101.

54 Zob. np. ANT, UWT, sygn. 2227: Pismo WdSW UWT w Tarnowie do Głównego Architekta Województwa w Tarnowie dotyczące odwołania od decyzji Naczelnika Miasta i Gminy w Dąbrowie Tarnowskiej w sprawie rozbiórki nielegalnie wybudowanej figury, 3 XII 1982 r., znak: Wz.III-6816/101/82, k. 1. Zob. także oznakowanie dokumentacji przy wykorzystaniu symbolu klasyfikacyjnego 6816 tamże, sygn. 2103-2477, 2482-2492, 2497, 2499, 2504-2517, 2521-2564, 2566-2567, 2569-2570, 3681-3707. Zob. także: tamże, sygn. 1627; AZ MUW Tar., UWT, sygn. 667, 668, 671.

55 Jednolity rzeczowy wykaz akt, s. 99.

$56 § 16$ pkt 7 Instrukcji kancelaryjnej, 1975.

$57 \S 15$ pkt 3 Instrukcji kancelaryjnej, 1987.

58 § 16 pkt 4 Instrukcji kancelaryjnej, 1975. 
w PRL i z tego względu jego wyznawcy mogą się gromadzić w celu odbywania modłów. W związku z tym niniejszą prośbę opiniuje się pozytywnie"59. Pod odpowiedzią nanoszono datę oraz pieczęć i podpis dyrektora wydziału. Natomiast forma brulionowa (korespondencyjna) polega na sporządzeniu przez referenta brulionowego projektu pisma załatwiającego sprawę ${ }^{60}$. Koncepty pism sporządzone odręcznie przez pracowników wydziału, niekiedy wraz z kopią czystopisu, nierzadko przechowywano w aktach spraw ${ }^{61}$. Po opracowaniu projektu pisma referent przedkładał go wraz $\mathrm{z}$ aktami sprawy aprobującemu w celu sprawdzenia prawidłowości projektowanego załatwienia sprawy. Czystopis sporządzany był przez maszynistki w hali maszyn, kancelarię $e^{62}$ lub referentów w wydziale ${ }^{63}$. Przekazywane do hali maszyn lub kancelarii koncepty pism były przepisywane zgodnie ze wskazówkami referentów. Pisma urzędowe zapisywano obustronnie. Takie postępowanie było zgodne z przepisami kancelaryjnymi ${ }^{64}$ oraz wytycznymi Wojewody Tarnowskiego promującymi oszczędność papieru ${ }^{65}$. Pisma załatwiające sprawę były dostosowane do blankietów korespondencyjnych A4 lub A5, w układzie poziomym lub pionowym. Racjonalne dobieranie formatu i gramatury papieru w zależności od rodzaju i treści korespondencji, obok przepisów kancelaryjnych, zalecało przytoczone powyżej zarządzenie Wojewody Tarnowskiego ${ }^{66}$.

Kancelaryjna postać pisma wychodzącego posiadała następujące cechy zewnętrzne, które odpowiadały układowi treści pisma na znormalizowanych

59 AZ MUW Tar., UWT, sygn. 656: Pismo A. Godka do Wydziału Społeczno-Administracyjnego Urzędu Miasta w Tarnowie, 22 XI 1987 r., nlb.

$60 \S 16$ pkt 6 Instrukcji kancelaryjnej, 1975.

61 Jako przykład podajmy projekt opracowania pt. „Rozwój obyczajowości i obrzędowości świeckiej w województwie tarnowskim” (AZ MUW Tar., UWT, sygn. 676, nlb.), sporządzony odręcznie przez pracownika WdSW. Przytoczony dokument zachował się w aktach wraz z dwoma egzemplarzami czystopisu. Stanowił on najprawdopodobniej załącznik do pisma przewodniego, które nie zachowało się w zasobie aktowym wydziału. Zob. także odręcznie sporządzony projekt opracowania pt. „Węzłowe problemy stosunków państwo-kościół przed trzecią wizytą papieża w Polsce” (ANT, UWT, sygn. 2565, nlb.). Zarówno czystopis, jak i pismo przewodnie nie zachowały się w zasobie aktowym WdSW.

$62 \S 20$ pkt 22 Instrukcji kancelaryjnej, 1975.

63 Tamże $\S 26$ pkt 1.

${ }^{64}$ Tamże $\S 26$ pkt 5.

${ }^{65}$ ANT, UWT, sygn. 3779: Pismo Wojewody Tarnowskiego do Dyrektorów UWT w Tarnowie, Prezydenta Miasta Tarnowa, Naczelników Miast, Miast i Gmin oraz Gmin w sprawie stosowania maksymalnej oszczędności zużycia papieru, 20 IV 1982 r., znak: BG-I 2030/20/82, k. 63-65.

66 Tamże, k. 63. 
blankietach korespondencyjnych ${ }^{67}$ : nazwę nadawcy w formie pieczęci nagłówkowej Wydziału do Spraw Wyznań odciskanej w lewym górnym rogu pisma. Pod nagłówkiem umieszczano znak sprawy. Miejsce wystawienia pisma i data umieszczane były w lewym górnym rogu. Nieco niżej, pośrodku wpisywano pełną nazwę odbiorcy (lub nazwisko) i adres. Dalszym elementem pisma była treść sprawy. W części wstępnej była ona poprzedzona zwięzłą informacją dotyczącą treści ${ }^{68}$. Na wstępie należało powołać się na znak pisma, którego dotyczy odpowiedź ${ }^{69}$. W zależności od potrzeb, treść pisma była mniej lub bardziej rozbudowana. Pod treścią pisma umieszczano pieczęć i podpis wystawcy. Jeżeli pismo miało formę pisma przewodniego, dołączano załączniki, odnotowując w jego lewej części, pod treścią pisma, ich liczbę i ewentualnie adresata lub listę adresatów otrzymujących pismo do wiadomości ${ }^{70}$. Na kopii odpowiedzi pisma, która była włączana do akt sprawy, odciskano pieczątkę ekspedycji. Dodatkowo zamieszczano wskazówki dotyczące wysłania czystopisu.

Pisma przychodzące otrzymywały w kancelarii odbiorcy szereg znaków kancelaryjnych. Pierwszą czynnością było odciśnięcie pieczęci wpływu, zwanej prezentą, prezentatą lub stampilą, którą wyciskano w kancelarii urzędu w górnej części pisma pod nagłówkiem ${ }^{71}$ lub w pierwszym wolnym miejscu dokumentu ${ }^{72}$. W przypadku korespondencji doręczanej bez otwierania, pieczęć odciskano

67 W 1976 r. wprowadzono normę PN-P-55315:76: Formularze - Blankiety korespondencyjne i firmowe, która przewidywała istnienie czterech typów blankietów, a mianowicie blankietu bezkopertowego, uproszczonego, zwykłego i reklamowego (P. Bunkowska, M. Jabłońska, H. Robótka, Współczesna dokumentacja typowa, (Biblioteka Zarządcy Dokumentacji, t. 5), Toruń 2014, s. 34-52. Zob. także H. Krystek, Organizacja pracy kancelaryjnej, [w:] Kancelaria i archiwum zakładowe. Podręcznik, red. Z. Pustuła, Warszawa 2006, s. 78-81). Standard zapisywania dat został z kolei uregulowany normą z 1982 r.: PN-82/N-01204 (§ 20 pkt 4 Instrukcji kancelaryjnej, 1987, s. 18-19). Na temat normalizacji blankietów korespondencyjnych zob. także: H. Robótka, Wspótczesna biurowość, s. 40-41.

68 Zob. np. AZ MUW Tar., UWT, sygn. 657: Pismo WdSW UWT w Tarnowie do Prezydenta Miasta Tarnowa, „sprawa: przydzielenia mieszkania zastępczego”, 24 VI 1985 r., znak: Wz.IV-6841/2/85, nlb.

69 Zob. np. tamże, sygn. 652: Pismo WdSW UWT w Tarnowie do Rady Kościoła Wolnych Chrześcijan w Bielsku Białej w sprawie wyrażenia zgody na powołanie placówki, 18 VI 1985 r., znak: Wz.IV-6841/1/85, nlb.

70 Zob. np. tamże, sygn. 668: Pismo WdSW UWT w Tarnowie w sprawie zezwolenia na budowę figury przydrożnej w Żelichowie, 19 VIII 1981 r., znak: Wz.III.6816/51/81, nlb.

${ }^{71}$ Zob. np. ANT, UWT, sygn. 1690: Pismo Wydziału Gospodarki Terenowej i Ochrony Środowiska UWT w Tarnowie do WdSW UWT w Tarnowie w sprawie remontu kościoła w Lisiej Górze, 15 XI 1976 r., znak: GT.IV.602-S/19/76, k. 67.

72 Zob. np. tamże, sygn. 2480: Pismo Urzędu Miejskiego w Tarnowie do WDSW 
na przedniej stronie koperty. Jeżeli pismo zostało nadesłane listem poleconym, w aktach sprawy wraz z pismem przychodzącym przechowywano także kopertę $^{73}$. Kolejnym elementem pism były noty marginalne zamieszczone na nich przez dyrektora wydziału, niekiedy również przez Wojewodę ${ }^{74}$. Wymienić należy wspomniane wcześniej dekretacje oraz wszelkiego rodzaju informacje notowane na piśmie (najczęściej na jego marginesie lub poniżej treści) dotyczące merytorycznego załatwienia sprawy, w tym trybu jej załatwienia ${ }^{75}$. W przypadku pism przychodzących referenci nanosili znak sprawy pod nagłówkiem pisma i znakiem sprawy nadanym przez wystawcę ${ }^{76}$ lub częściej w górnej, środkowej części pisma ${ }^{77}$.

W podziale klasyfikacyjnym dla każdej końcowej pozycji w jednolitym rzeczowym wykazie akt referent powinien założyć spis spraw i odpowiadającą mu teczkę do przechowywania w niej spraw ostatecznie załatwionych ${ }^{78}$. Przepisy kancelaryjne proponowały zakładanie spisów spraw i teczek oddzielnie na każdy rok kalendarzowy. W przypadku małej liczby korespondencji dopuszczały możliwość prowadzenia teczki dłużej niż jeden rok. Pozwalały także na wydzie-

UWT w Tarnowie w sprawie umorzenia podatku dochodowego duchownemu, 7 VIII 1975 r., znak: Fn. Ew. 55/75, k. 1.

${ }^{73}$ Zob. np. AZ MUW Tar., UWT, sygn. 641: Pismo Ministra Urzędu do Spraw Wyznań do Dyrektora WdSW UWT w Tarnowie w sprawie jednodniowej narady, 14 II 1983 r., znak: GM-001/3/83, bp.; tamże, sygn. 664: Pismo UdSW do Dyrektora WdSW UWT w Tarnowie w sprawie komunikatu ze 166 Konferencji Episkopatu Polski, 12 XII 1978 r., znak: RK-420/51/78, nlb.

${ }^{74}$ Zob. np. tamże, sygn. 664: Pismo Ministra Kierownika UdSW do wojewody tarnowskiego, Jana Sokołowskiego, w sprawie oddelegowania Dyrektora WdSW w Tarnowie na naradę dotyczącą aktualnych problemów polityki wyznaniowej, 6 X 1978 r., znak: OG-001/4/78, nlb.; tamże, sygn. 643: Pismo Ministra Kierownika UdSW do wojewody tarnowskiego w sprawie oddelegowania Dyrektora WdSW w Tarnowie na naradę, 25 VIII 1982 r., znak: OG-001/3/82, nlb.

75 Zob. np. tamże, sygn. 666: Pismo Dyrektora Zespołu UdSW do WdSW UWT w Tarnowie w sprawie upamiętnienia miejsc zbiorowych straceń ludności żydowskiej na terenie województwa tarnowskiego, 1 II 1985 r., znak: NK-803/18/13/2/85, nlb.; tamże: Pismo WdSW UWT w Tarnowie do Dyrektora Zespołu UdSW w Warszawie, Tadeusza Dusika, w sprawie aktualnego stanu upamiętnienia miejsc eksterminacji ludności żydowskiej na terenie województwa tarnowskiego, 11 X 1984 r., znak: WZ. IV-6876/11/84, nlb. Szerzej na temat not marginalnych zob. H. Robótka, Opracowanie i opis, s. 36-37.

76 Zob. np. ANT, UWT, sygn. 3756: Pismo WdSW UWT w Nowym Sączu do WdSW UWT w Tarnowie w sprawie nadesłania akt osobowych duchownego, 20 IX 1978 r., znak: WZ-40/068/78, k. 265.

77 Zob. np. AZ MUW Tar., UWT, sygn. 641: Pismo poufne Dyrektora Zespołu UdSW do Dyrektora WdSW UWT w Tarnowie w sprawie informacji dotyczącej budownictwa sakralnego, 3 VII 1983 r., znak: RK-610/80/83, nlb.

78 § 11 pkt 1 Instrukcji kancelaryjnej, 1975. 
lenie określonych spraw w osobne zbiory i prowadzenia ich w podteczkach ${ }^{79}$. Referenci wydziału prowadzili spisy spraw na specjalnie przeznaczonych do tego celu formularzach służących do chronologicznego rejestrowania spraw wpływających lub zapoczątkowanych, które uzupełniane były maszynowo ${ }^{80}$ bądź odręcznie ${ }^{81}$. Stanowią one przewodnik po zawartości teczki, służą odszukiwaniu spraw, a także kontroli terminowości ich załatwienia ${ }^{82}$. Są ponadto cennym źródłem wiedzy na temat stanu zachowania archiwaliów, umożliwiając wykazanie ewentualnych braków wśród zachowanych akt spraw.

Formularz spisu spraw najczęściej umieszczano luzem na wierzchu teczki ${ }^{83}$. W przypadku prowadzenia teczek wieloletnich spis spraw na każdy kolejny rok układany był na wierzchu akt spraw prowadzonych w danym roku ${ }^{84}$. Kolejne lata przeważnie oddzielano papierową przekładką, na której zapisywano rok, w którym zarejestrowano sprawy. Zdarzało się także, że referent na jednym formularzu spisu spraw prowadził spisy dla odrębnych lat, oddzielając od siebie zapisy z poszczególnych lat ${ }^{85}$. Niekiedy formularz spisu spraw wszywano zszywkami na odwrocie wierzchniej okładki teczki ${ }^{86}$ lub spinano je spinaczem z aktami pierwszej sprawy ${ }^{87}$. Akta poszczególnych spraw bardzo często oddzielano od siebie, spinając je metalowymi spinaczami. Mając na uwadze ułatwienie pracy referentom, przepisy instrukcji umożliwiały przechowywanie spisów spraw bieżącego roku nie w teczkach założonych według jednolitego rzeczowego wykazu akt, ale w oddzielnej teczce podręcznej, która powinna zostać opatrzona tytułem „Spisy spraw do teczek symbol...”"8. Takie rozwiązanie, ze względu na dużą liczbę spraw rejestrowanych w ciągu roku, stosowane było przez referenta zajmującego się sprawami dotyczącymi budownictwa sakralnego i kościelnego (symbol Wz.III) ${ }^{89}$. Zgodnie z przepisami po zakończeniu roku spisy powinny zostać odłożone do właściwych teczek rzeczowych.

79 Tamże, § 11 pkt 3. Prowadzenie przez referentów WdSW spraw w podteczkach należało do rzadkości. Przykład stanowi jednostka kancelaryjna ANT, UWT, sygn. 2079.

${ }^{80}$ Zob. np. ANT, UWT, sygn. 2533, k. 1-3; tamże sygn. 2534, k. 1-3; tamże sygn. 2535, k. 1-5.

${ }^{81}$ Zob. np. AZ MUW Tar., UWT, sygn. 641, nlb.

${ }^{82}$ H. Robótka, Opracowanie i opis, s. 30-31.

83 Zob. ANT, UWT, sygn. 3755, nlb.; tamże, sygn. 3810, k. 1; tamże, sygn. 3837, nlb.

${ }^{84}$ Zob. AZ MUW Tar., UWT, sygn. 660, nlb.

85 Tamże, sygn. 661, nlb.

${ }^{86}$ Zob. np. tamże, sygn. 640, nlb.

${ }_{87}$ Zob. np. tamże, sygn. 673, nlb.

$88 \S 11$ pkt 5 Instrukcji kancelaryjnej, 1975.

89 Zob. ANT, UWT, sygn. 2533, k. 1-3; tamże, sygn. 2537, k. 1-5; tamże, sygn. 2535, 
Ten obowiązek nie został jednak dopełniony. Analiza aktowa wykazała, że pracownicy nie zawsze prowadzili spisy spraw, a prowadzone przez nich spisy często nie były dokładnie wypełniane (szczególnie rubryki w części górnej) lub były wypełniane nieprawidłowo ${ }^{90}$. Formularze spisów spraw najdokładniej prowadzone były przez referentów zajmujących się sprawami cmentarnictwa wyznaniowego i komunalnego, organizacją instytucji wyznaniowych oraz regulacją prawną majątków rzymskokatolickich (symbol Wz.IV), a także sprawami budownictwa sakralnego i kościelnego (symbol Wz.III). Mniej starannie spisy spraw były prowadzone przez referenta zajmującego się m.in. sprawami ogólnoorganizacyjnymi wydziału (symbol Wz.I). Zdarzało się, iż niektórzy referenci w ogóle nie prowadzili spisów spraw ${ }^{91}$.

Akta spraw przechowywano najczęściej w wiązanych teczkach papierowych lub skoroszytach, rzadziej w teczkach plastikowych i segregatorach. Prawidłowy opis jednostki kancelaryjnej powinien zawierać pełną nazwę urzędu i wydziału, który ją wytworzył (w tym wypadku Urząd Wojewódzki w Tarnowie, Wydział do Spraw Wyznań). Należało ją umieścić u góry, na środku okładki. W prawym górnym rogu należało zamieścić kategorię archiwalną, natomiast w lewym górnym rogu znak teczki, na który składał się symbol komórki organizacyjnej i symbol klasyfikacyjny z jednolitego rzeczowego wykazu akt. Ważnym elementem opisu teczki był jej tytuł, który powinien być zgodny z hasłem z wykazu akt oraz informować o zawartości teczki. Pod tytułem należało umieścić ewentualny tom teczki i daty skrajne akt (datę pierwszego i ostatniego pisma $)^{92}$. Na podstawie przeprowadzonych badań można stwierdzić, że referenci nie opisywali teczek spraw ostatecznie załatwionych zgodnie w wymogami instrukcji kancelaryjnej. Na teczkach nie zamieszczano nazwy wytwórcy akt. Tytuły teczek, które z założenia miały odpowiadać poszczególnym hasłom z wykazu akt, w rzeczywistości często nie spełniają tego wymogu. Różna jest także jakość opisów i ich wartość informacyjna, co można wiązać z kompetencjami i kwalifikacjami zawodowymi poszczególnych pracowników wydziału. Nie brakuje w pozostałości aktowej wydziału teczek noszących tytuły: „Sprawy »warszawskie«. Pisma przewodnie, Informacje, Notatki, Zarządzenia resortowe”, „Sprawy ogólne”, „Różne”, „Decyzje”, „Wykaz”, „Notatki”,

k. 1-5; tamże, sygn. 2534, k. 1-5; tamże, sygn. 2482, k. 1-7. Największa liczba spraw zarejestrowanych w danym roku wyniosła 99, najmniejsza natomiast 45 .

${ }_{90}$ Tamże, sygn. 3771, nlb.; tamże, sygn. 3757, nlb.

${ }^{91}$ Zob. np. tamże, sygn. 3786, 3840; AZ MUW Tar., UWT, sygn. 652-653.

${ }_{92}$ § 35 Instrukcji kancelaryjnej, 1975. 
„Informacja”, „Procesja”, „Wizytacja”, „Konserwator”. Nierzadko tytuły teczek nanoszone były ołówkiem ${ }^{93}$. Pod tytułem lub obok niego zapisywano daty skrajne dokumentacji zgromadzonej w teczce. Najczęściej zapisywano daty roczne, które często nie odpowiadały datom rozpoczęcia (data pierwszego pisma wszczynającego sprawę) i zakończenia teczki (data ostatniego pisma w sprawie, której dotyczy). Zdarza się również, że opisy teczek nie posiadają dat skrajnych. Na obwolutach najczęściej nie nanoszono kategorii archiwalnej, która powinna odpowiadać hasłom klasyfikacyjnym z wykazu akt, tym samym referenci nie kwalifikowali akt do właściwych kategorii w trakcie ich narastania94. Częstą praktyką było natomiast umieszczanie na obwolutach znaku teczki ${ }^{95}$, przy czym był on najczęściej uzupełniany o dwie ostatnie cyfry roku, w którym wszczęto sprawy zgromadzone w danej jednostce kancelaryjnej (np. Wz.I-6822/7896). W przypadku akt administracyjnych dodatkowym elementem, którym referent uzupełniał symbol teczki, było oznaczenie odnoszące się do rodzaju dokumentacji w niej zgromadzonej (np. Wz.I. 6826/M/80"7, gdzie symbol „M”, jak wspomniano wcześniej, oznaczał korespondencję przychodzącą w postaci zarządzeń i pism ministerialnych). Referenci wydziału najczęściej zapisywali symbol teczki w górnej środkowej części obwoluty. Powyższy zapis powielano na formularzu spisu spraw, zamieszczając go w górnej, środkowej części dokumentu.

Prowadzono teczki jednoroczne i wieloletnie. Często zakładano teczki według uznania referenta i w miarę bieżących potrzeb ${ }^{98}$. Dokładniejsze opisy jednostek nadawane były przez referenta zajmującego się sprawami cmentarnictwa. W tym przypadku zapisywano daty skrajne dzienne i roczne, które notowano w lewym dolnym rogu obwoluty. Daty roczne powtarzano następnie w jej prawym górnym rogu, jednak nie zawsze pokrywały się one z datami zapisanymi niżej. Na środku okładki zapisywano tytuł (np. „Cmentarze żydowskie na terenie woj. tarnowskiego"), natomiast w dolnej części obwoluty, po prawej stronie zapisywano symbol teczki (Wz.IV-6876). Dodatkowo opisywano grzbiet obwoluty, zapisując na nim tytuł jednostki i symbol teczki. Opisy grzbietów teczek zostały również uzupełnione o ich kolejne numery porządkowe od 1 do 6 .

${ }_{93}$ Zob. ANT, UWT, sygn. 2207, 2518.

${ }^{4}$ W pozostałości aktowej tarnowskiego WdSW znajdują się nieliczne teczki aktowe oznaczone kategorią archiwalną, np.: tamże, sygn. 2500, 3787.

95 Zob. np. tamże, sygn. 2538, 2585, 3754, 3786.

96 Tamże, sygn. 3757.

${ }_{97}$ Tamże, sygn. 3771.

98 Zob. np. jednostki opatrzone tytułami: „Relacja ze spotkania w Warszawie” (AZ MUW Tar., UWT, sygn. 675); „Obrzędowość i obyczajowość” (tamże, sygn. 676). 
Akta spraw załatwionych pozostawały przez pewien czas $\mathrm{w}$ wydziale jako tzw. akta podręczne. Po wyznaczonym w przepisach kancelaryjnych czasie powinny zostać przekazane do archiwum zakładowego ${ }^{99}$. Przekazywanie akt powinno odbywać się na podstawie spisów zdawczo-odbiorczych, sporządzanych odrębnie dla akt kategorii „A” i „B”. Następnie, po upływie określonego czasu przechowywania w archiwum zakładowym, akta powinny zostać przekazane na zniszczenie lub do archiwum państwowego. Przepisy kancelaryjne nakładały na referentów obowiązek właściwego opracowania materiałów przed ich przekazaniem do archiwum zakładowego. Szczególną uwagę należało zwrócić na uporządkowanie materiałów archiwalnych (kat. „A”). Przepisy wymagały nadania pismom w obrębie spraw i sprawom w teczce właściwego porządku. Układ pism w obrębie spraw i spraw w teczkach powinien być chronologiczny. Oznacza to takie ułożenie akt wewnątrz teczek, aby sprawy następowały po sobie według liczb porządkowych spisów spraw (poczynając od sprawy zarejestrowanej pod numerem $1 \mathrm{w}$ spisie spraw, która powinna zostać ułożona na wierzchu teczki). W obrębie sprawy pisma należało ułożyć chronologicznie, zaczynając od rozpoczynającego daną sprawę ${ }^{100}$. Referenci WdSW, podobnie jak zdecydowana większość pracowników innych komórek organizacyjnych urzędu, postępowali odwrotnie. W teczkach czy segregatorach nie łączono spraw zgodnie z wytycznymi przepisów kancelaryjnych. Sprawa zarejestrowana pod numerem pierwszym znajduje się na spodzie teczki, a ostatnia na jej wierzchu. Taki układ akt, praktyczny w trakcie załatwiania spraw, został podyktowany budową skoroszytów i segregatorów ${ }^{101}$. Przepisy wymagały także m.in. wyłączenia z akt dubletów, właściwego opisania teczek na ich zewnętrznej stronie oraz w przypadku kat. „A” przesznurowania całości akt i ponumerowania poszczególnych stron ołówkiem i oznaczenie na zewnętrznej spodniej stronie okładki liczby stron zawartych w teczce ${ }^{102}$. W świetle przeprowadzonej analizy można stwierdzić, że referenci wydziału nie stosowali się w praktyce do przepisów kancelaryjnych.

99 Zgodnie z przepisami kancelaryjnymi z 1975 r. akta spraw ostatecznie załatwionych należało przekazać do archiwum zakładowego po upływie dwóch lat (§ 36 pkt 2 Instrukcji kancelaryjnej, 1975), natomiast instrukcja z 1987 r. zalecała przekazanie akt po jednym roku (§ 34 pkt 2 Instrukcji kancelaryjnej, 1987).

$100 \S 38$ pkt 1 Instrukcji kancelaryjnej, 1975.

${ }^{101}$ I. Radtke, Organizacja pracy kancelaryjnej, [w:] Archiwistyka praktyczna dla archiwistów zakładowych, red. C. Kłys, Poznań 1986, s. 55, s. 34, taż, Narastanie zespołów akt $w$ zakładach pracy $w$ świetle obowiązujących przepisów kancelaryjnych, „Archeion” 1968 , t. 48 , s. $17-18$.

$102 \S 38$ pkt 1 Instrukcji kancelaryjnej, 1975. Zob. także: I. Radtke, Organizacja pracy, s. $60-62$. 
Akta spraw zostały przekazane do archiwum zakładowego w stanie nieuporządkowanym. Ponadto liczne braki poszczególnych pism w aktach spraw, a niekiedy całych spraw, wskazują na brak dbałości referentów o kompletność akt spraw.

Podsumowując, działalność kancelaryjną Urzędu Wojewódzkiego w Tarnowie, w tym WdSW funkcjonującego w jego strukturze, regulowały normatywy kancelaryjno-archiwalne o charakterze ogólnopolskim: instrukcja kancelaryjna, jednolity rzeczowy wykaz akt oraz instrukcja o organizacji i zakresie działania archiwum zakładowego. Regulacje wprowadzone w 1975 r. i 1976 r. obowiązywały do 1990 r., z wyjątkiem instrukcji kancelaryjnej, która została zmieniona w 1987 r. Ogólnokrajowy charakter tych przepisów stworzył warunki do funkcjonowania jednolitej kancelarii w urzędach wojewódzkich na terenie całego kraju. W urzędzie funkcjonował bezdziennikowy system kancelaryjny oparty na jednolitym rzeczowym wykazie akt o dziesiętnym sposobie sygnowania. W zdecentalizowanym wariancie biurowości, który obowiązywał w tej jednostce, do wykonywania czynności kancelaryjnych zobowiązani byli pracownicy kancelarii, sekretariatów wojewody, hali maszyn, archiwum zakładowego, a także wszyscy referenci, w kompetencjach których pozostawało merytoryczne załatwienie sprawy. Tryb i zasady prawidłowego wykonywania czynności kancelaryjnych określała instrukcja kancelaryjna. Przepisy kancelaryjne nie zapewniły prawidłowego narastania dokumentacji w WdSW. Można zauważyć brak dbałości w wykonywaniu czynności kancelaryjnych przez referentów wydziału, a w niektórych przypadkach niestosowanie się przez nich do przepisów kancelaryjnych, co negatywnie wpłynęło na proces powstawania i narastania dokumentacji WdSW oraz stan jej zachowania. Dokumentacja powstała w wyniku realizacji zadań przez wydział, odzwierciedla jego działalność oraz zakres formalnych i rzeczywistych kompetencji. Dzięki analizie archiwaliów wytworzonych i zgromadzonych w toku jego funkcjonowania możemy obecnie ustalić, w jaki sposób referenci w nim zatrudnieni realizowali swoje obowiązki. Ze względu na treść, przedmiot sprawy oraz walory poznawcze posiadają one dużą wartość naukową.

\section{Bibliografia}

Bagieński, Włodzimierz. Procesy archiwotwórcze akt miejskich na Mazowszu na przykładzie Piaseczna w latach 1815-1950. Warszawa: DiG, 1999.

Barszcz, Anna. Prezydium Rady Ministrów i Urząd Rady Ministrów jako wytwórcy państwowego zasobu archiwalnego (1945-1996). Warszawa: Naczelna Dyrekcja Archiwów Państwowych, 2014. 
Bielaszka-Podgórny, Barbara. „Wartość badawcza archiwaliów Wydziału do spraw Wyznań Urzędu Wojewódzkiego w Tarnowie jako źródła do dziejów aparatu wyznaniowego PRL”. Pamięć i Sprawiedliwość, nr 33 (2019): 438-57.

Bielaszka-Podgórny, Barbara. „Organizacja i zakres kompetencji Wydziału do Spraw Wyznań Urzędu Wojewódzkiego w Tarnowie w świetle archiwaliów zespołu «Urząd Wojewódzki w Tarnowies”. W Urząd do spraw Wyznań: struktury, działalność, ludzie, zredagował Rafał Łatka, 1 [w druku].

Bunkowska, Paulina, Marlena Jabłońska, i Halina Robótka. Wspótczesna dokumentacja typowa. Biblioteka Zarządcy Dokumentacji 5. Toruń: Wydawnictwo Naukowe Uniwersytetu Mikołaja Kopernika, 2014.

Chmielewski, Zdzisław. Procesy aktotwórcze w polskich urzędach miejskich 1918-1939. Szczecin; Warszawa: Naczelna Dyrekcja Archiwów Państwowych, 1983.

Degen, Robert. „Zarządzanie dokumentacją w polskich badaniach”. W Zarządzanie dokumentacją. Badania i dydaktyka, zredagowali przez Robert Degen i Marlena Jabłońska, 37-58. Biblioteka Zarządcy Dokumentacji 7. Toruń: Wydawnictwo Naukowe Uniwersytetu Mikołaja Kopernika, 2016.

Szpor, Grażyna, red. Dokumentacja elektroniczna w podmiotach publicznych: zagadnienia podstawowe. Stan prawny na 1 lipca 2013 r. Warszawa: Wolters Kluwer Polska, 2013.

Duranti, Luciana, i Patricia C. Franks, red. Encyclopedia of archival science. Lanham, Maryland: Rowman \& Littlefield, 2015.

„Instrukcja kancelaryjna dla urzędów terenowych organów administracji państwowej.” Ministerstwo Administracji, Gospodarki Terenowej i Ochrony Środowiska, 1975.

„Instrukcja kancelaryjna dla urzędów terenowych organów administracji państwowej”. Urząd Rady Ministrów, 1987.

„Jednolity rzeczowy wykaz akt dla terenowych organów administracji państwowej”. Ministerstwo Administracji, Gospodarki Terenowej i Ochrony Środowiska, 1975.

Karpiński, Tomasz. „Procesy akto- i archiwotwórcze w sądownictwie wojskowym w latach 1945-2010 na przykładzie sądów poznańskich.” Rozprawa doktorska, Uniwersytet im. Adama Mickiewicza w Poznaniu, 2013. http://hdl.handle.net/10593/8779

Krystek, Henryk. „Organizacja pracy kancelaryjnej.” W Kancelaria i archiwum zakładowe: podręcznik, zredagował Zbigniew Pustuła, 63-89. Warszawa: Stowarzyszenie Archiwistów Polskich, 2006

Leśkiewicz, Rafał. Wojskowy Sąd Rejonowy w Poznaniu (1946-1955): organizacja, funkcjonowanie, procesy archiwotwórcze. Monografie / Instytut Pamięci Narodowej - Komisja Ścigania Zbrodni przeciwko Narodowi Polskiemu 58. Poznań: Instytut Pamięci Narodowej - Komisja Ścigania Zbrodni przeciwko Narodowi Polskiemu, 2009.

Misztal, Henryk, i Artur Mezglewski. „Zarys kompetencji, styl działania i cele Urzędu ds. Wyznań." W Prawo i polityka wyznaniowa w Polsce Ludowej: materiały z II Ogólnopolskiego Sympozjum Prawa Wyznaniowego (Kazimierz Dolny, 26-28 października 2004), zredagowali Artur Mezglewski, Piotr Stanisz i Marta Ordon, 33-70. Lublin: Wydawnictwo KUL, 2005.

Perłakowska, Ewa. „Ewolucja zarządzania dokumentacją w podmiotach publicznych.” W Dokumentacja elektroniczna w podmiotach publicznych, zredagowane przez Grażyna Szpor, 23-29. Warszawa: Wolters Kluwer, 2013. 
Polski Komitet Normalizacji, Miar i Jakości. Formularze - Blankiety korespondencyjne firmowe. PN-76/P-55315. Warszawa, ustanowiona 07.07.1976; wycofana 16.01.2006.

Polski Komitet Normalizacji, Miar i Jakości. Numeryczne zapisywanie dat i czasu dnia. PN-N-01204:1982. Warszawa, ustanowiona 26.01.1982; wycofana 08.10.1990.

Pudłowski, Leszek. „Archiwistyka a zarządzanie dokumentacją: rola modeli cyklu życia i continuum dokumentacji w postrzeganiu wzajemnych związków." W Zatrzymać przeszłość, dogonić przyszłość: pamiętnik VI Powszechnego Zjazdu Archiwistów Polskich, Wrocław 5-7 września 2012 r., zredagowali Waldemar Chorążyczewski i Krzysztof Stryjkowski, 51-78. Warszawa: Stowarzyszenie Archiwistów Polskich, 2013.

Pudłowski, Leszek. „Model cyklu życia dokumentacji.” Archeion 115 (2014): 177-225.

Radtke, Irena. „Kancelaria współczesna.” Archeion 100 (1999): 28-49.

Radtke, Irena. „Narastanie zespołów akt w zakładach pracy w świetle obowiązujących przepisów kancelaryjnych." Archeion 48 (1968): 7-23.

Radtke, Irena. „Organizacja pracy kancelaryjnej.” W Archiwistyka praktyczna dla archiwistów zakładowych, zredagował Czesław Kłys, 26-83. Poznań: Zakład Doskonalenia Zawodowego, 1986.

Robótka, Halina. Kancelaria urzędów administracji państwowej II Rzeczypospolitej: procesy aktotwórcze. Toruń: Wydawnictwo UMK, 1993.

Robótka, Halina. Opracowanie i opis archiwaliów: podręcznik akademicki. Toruń: Wydawnictwo Naukowe Uniwersytetu Mikołaja Kopernika, 2010.

Robótka, Halina. Wspótczesna biurowość: zagadnienia ogólne. Biblioteka Zarządcy Dokumentacji 1. Toruń: Wydawnictwo Naukowe Uniwersytetu Mikołaja Kopernika, 2010.

„Rozporządzenia Rady Ministrów z dnia 30 maja 1975 r. w sprawie zasad organizacji urzędów terenowych organów administracji państwowej." Dziennik Ustaw Polskiej Rzeczypospolitej Ludowej, nr 17, poz. 93 (1975).

„Rozporządzenie Rady Ministrów z dnia 9 lipca 1975 r. w sprawie szczegółowego zakresu działania Ministra Administracji, Gospodarki Terenowej i Ochrony Środowiska." Dziennik Ustaw Polskiej Rzeczypospolitej Ludowej, nr 26, poz. 136 (1975).

Ryszewski, Bohdan. Problemy i metody badawcze archiwistyki. Rozprawy / Uniwersytet Mikołaja Kopernika. Toruń: Uniwersytet Mikołaja Kopernika, 1985.

Ryszewski, Bohdan. „Rozwój form kancelaryjnych w Polsce XIX i XX w.” W Nauki pomocnicze historii na XI Powszechnym Zjeździe Historyków Polskich w Toruniu, zredagowat Andrzej Tomczak, 74-89. Warszawa; Łódź: Państwowe Wydawnictwo Naukowe, 1976.

„Ustawa z dnia 28 maja 1975 r. o dwustopniowym podziale administracyjnym Państwa oraz o zmianie ustawy o radach narodowych." Dziennik Ustaw Polskiej Rzeczypospolitej Ludowej, nr 16, poz. 91 (1975).

Urząd Wojewódzki w Tarnowie. Archiwum Zakładowe Małopolskiego Urzędu Wojewódzkiego w Krakowie Delegatura w Tarnowie.

Urząd Wojewódzki w Tarnowie [1945] 1975-1998. Archiwum Narodowe w Krakowie Oddział w Tarnowie. 